\title{
Predicting the Halal Food Consumption of Indonesian Moslem Students: an Application of Theory of Planned Behaviour
}

\author{
Siti Helmyati ${ }^{1,2 *}$, Rahma Yuni Siagian', Fatma Zuhrotun Nisa ${ }^{1}$, \\ Salima Radhiya ${ }^{1}$, Endri Yuliati ${ }^{3}$ \\ ${ }^{1}$ School of Health Nutrition, Faculty of Medicine, Public Health and Nursing, \\ Universitas Gadjah Mada, Yogyakarta 55281, Indonesia \\ ${ }^{2}$ Center for Health and Human Nutrition, Faculty of Medicine, Public Health and Nursing, \\ Universitas Gadjah Mada, Yogyakarta 55281, Indonesia \\ ${ }^{3}$ School of Nutrition Science, Respati University of Yogyakarta, Yogyakarta 55281, Indonesia
}

\begin{abstract}
The study aimed to predict halal food consumption behavior among Moslem students in three different universities in Yogyakarta City. Determinants to explain the halal food consumption was developed based on theory of planned behavior. The research applied cross-sectional design with total respondents of 168 Moslems students from State University, Islamic University, and Catholic University in Yogyakarta. The score of attitude, knowledge, subjective norm, perceived behavioral control and halal food consumption behavior were collected through a questionnaire. The data was analysed using Kruskall-Wallis and Multiple Linear Regression test. The study found that the score of knowledge in Islamic State and State University was higher than in Catholic University ( 7.43 vs 7.29 vs 7.09 ). The highest score of attitude was 51.52 in State University compared to Islamic State University and Catholic University (49.8 vs 47.61). The highest score of subjective norm was also in State University with the score of 3.59 while the score of halal food consumption behaviour were higher in State and Islamic State University compared to Catholic University ( 9.18 vs 9.18 vs 7.89 ). From those categories, the score of all variables except for the knowledge was statistically different between the three universities $(p<0.05)$. It was concluded that the behavior of halal food consumption among Moslem students in Yogyakarta City may be predicted from the knowledge, attitude, subjective norm, and perceived behavioral control. These findings help to explain why the Moslem students in Yogyakarta eat halal food. Further research is needed to determine whether there are factors affecting halal food consumption behavior and how to improve it.
\end{abstract}

Keywords: attitude, halal food, knowledge, perceived behavioral control, subjective norm

\section{INTRODUCTION}

Indonesia has the largest population of Moslem in the world. The Pew Forum on Religion and Public Life (2011) stated that Indonesian Moslem accounted for $13 \%$ of total Moslems population in the world. Hence, halal food is an essential need for Moslems. The word halal means permitted or lawful. It arranges what kind of foods are permissible to eat according to the holy book, 'Quran. Halal foods refer to all foods which do not contain a prohibited material, and prepared according to the Islamic law (Khattak et al. 2015). The halalness of the products are determined by Majelis Ulama Indonesia (MUI) through several investigation processes (Othman et al. 2016; Aziz 2017). However, there were Indonesian Moslems who do not understand the concept of halal. A study showed that Indonesian
Moslem did not always consume halal foods and sometimes it comes second after the taste (Soesilowati 2009; Ismoyowati 2015).

The halalness of Indonesian street food is also a big issue since many of them were not certified as halal by the legal institution (Anjani et al. 2008; Fithriana \& Kusuma 2018). Indonesian Ministry of Religion (2013) reported that the knowledge of Indonesian Moslems about halal certification as the only guide to decide the food halalness was low. It was estimated $47 \%$ of the respondents did not know about halal certification law in Indonesia. It was also reported that $13 \%$ of the respondents always consumed foods without halal label and $15 \%$ is often come to the restaurant without halal certificate. Based on these data, it was necessary to investigate the factors affecting the intention of Indonesian Moslems on halal food consumption behavior.

"Corresponding Author: tel: +6227454775, email: siti.helmyati@gmail.com 
Halal food consumption as human behavior can be approached from many angles, one theory that has been proven to be able to explain food choices behaviour is the theory of planned behavior. Khalek and Ismail (2015) stated that using theory of planned behavior could explain why the generation Y in Malaysia eat halal food. It was also in accordance with a study by Aditami (2016) which showed significant impact of attitude, subjective norm, and perceived behavioral control on bakery product consumption. A study by Fahmi (2017) also mentioned that attitude and subjective norm about halal labeling may have positive and significant effect towards intention and behavior of halal foods consumption. Some other studies were also stated similar findings that the theory of planned behavior could be significant in predicting factors toward certain human behavior (Rahim \& Junos 2012; Alam \& Sayuti 2011; Soon \& Wallace 2017).

The theory focuses on the influencing factors of behaviour such as attitude toward behaviour, subjective norm, and perceived behavioral control (Ajzen 1991). Ajzen and Fishbein (2005) explained that the three factors greatly affect every intention of human behavior including food consumption. In attitude aspect, Golnaz et al. (2010) added awareness and knowledge as other sub-aspects thus the aspects of knowledge and theory of planned behavior are the framework of this study. It was aimed to see whether halal food consumption behavior could be explained through the attitude, knowledge, subjective norm, and perceived behavioral control of the subjects.

Many studies about the perception of halal foods have been done in Indonesia (Soesilowati 2009; Listyoningrum 2012; Soesilowati \& Yuliana 2013; Magfiroh 2015; Ismoyowati 2015). However, the studies were limited in Moslems environment and or conducted among adults. The present study brings the novelty which is the replication and extension of the topic. It was conducted among Yogyakarta Moslems students which derived from three different university backgrounds. One group is an Islamic State University (ISU) and the other groups are a Catholic University (CU) and State University (SU). Yogyakarta City was chosen since it was known as "City of Students", where the students from many different culture and religion came to study. These difference in education background and religion heterogeneity may lead to different knowledge, attitude, subjective norm, and perceived behavioral control on halal food consumption of the Moslem students. This study aimed to predict halal food consumption behavior among Moslem students in three different universities in Yogyakarta City.

\section{METHODS}

\section{Design, location, and time}

The research was conducted using crosssectional study design. It was carried out in three different universities; State University (SU), Islamic State University (ISU), and Catholic University (CU). The data was collected using questionnaire to measure the knowledge, attitude, subjective norm, and perceived behavioral control of the students toward halal food consumption.

\section{Sampling}

The respondents of this study were Moslem students from SU, ISU, and CU. The size of the respondents was calculated based on formula from Dahlan (2009) with $\alpha=5 \%, \beta=10 \%$, and $\mathrm{r}=0.273$ from Soesilowati (2011). There were 168 Moslem students joined the study and were purposively divided into 56 students from SU, 56 students from ISU, and 56 students from CU. Simple random sampling method was used to choose the respondents from each university according to their registered faculty. Moslem students from Faculty of Husbandry SU, Faculty of Science and Technology ISU, and Fa-culty of Teaching, Educational Science, and Li-terature CU were accidentally chosen to follow the study. This research has been approved by Medical and Health Research Ethics Committee of Faculty of Medicine, Public Health, and Nursing, Universitas Gadjah Mada, Ref: KE/FK/355/EC.

\section{Data collection}

There were four independent variables measured in the study, knowledge, attitude, subjective norm, and perceived behavioral control. These variables were required to predict the behavior of the Moslem students toward halal food consumption. All variables used in this study were in ratio scale and collected using a questionnaire with a total of 60 questions. It consisted of 14 multiple choice questions to measure the knowledge, 16 statements with Likert Scale to measure attitude, 7 questions with Guttmann Scale to measure the subjective norm, 8 statements with Likert Scale to measure the perceived behavioral control and 15 questions with Guttmann Scale to measure the halal food consumption behavior. The Likert Scale consisting 4 scales; "strongly agree", "agree", "disagree", "strongly disagree" 
while the Gutmann Scale consisting two scales; "Yes" and "No" (Sugiyono 2009). Before the study began, the questionnaire was tested to 30 students from each university to determine its validity and reliability.

\section{Data analysis}

The reliability of the questionnaire was tested using Alfa Cronbach test which considered reliable if the point is more than 0.601 (Nugroho 2011). The questionnaire validity has been determined using Pearson test which considered to be significant if the correlation factor was more than +0.30 . Using software STATA 13.1 we tested normality of data distribution by applying Saphiro-Wilk test while the mean difference of the variables among three universities are compared using One-Way ANOVA. Multiple Linear Regression test were conducted to predict the halal food consumption behavior from four independent variables.

\section{RESULTS AND DISCUSSION}

The subjects were 168 students from three different universities. The first is SU where heterogeneous students from different culture and religion enrolled. The second is ISU where all of the students are Moslems, and the third is CU where the majority of students are Christians. Most of the subjects were female, more than 18 years old, living in boarding house, and had non-pesantren (Islamic boarding house) background (Table 1).

The score of knowledge, attitude, subjective norm, perceived behavioral control and halal food consumption behavior

The dependent variable of the study was halal food consumption behavior that may be predicted from the attitude, knowledge, subjective norm, and perceived behavioral control as the independent variables. Table 2 shows that only the score of attitude, subjective norm, perceived behavioral control, and behavior of consuming halal food among all respondents from the three universities were significantly different $(p<0.05)$. The score of attitude and subjective norm were the highest in SU followed by ISU and CU. Meanwhile, the score of perceived behavioral control and halal food consumption behavior were higher in SU and ISU than in CU. ISU had the highest score of knowledge although it was not significant $(\mathrm{p}>0.05)$. These results suggested that Islamic or non-Islamic environment, as re-presented in the name of the Universities does not guarantee higher score of knowledge, attitude, subjective norm, perceived behavioral control, and halal food consumption behavior.

Knowledge can be defined as the result of "knowing" process. The process involves

Table 1. Characteristics of subjects

\begin{tabular}{|c|c|c|c|c|c|}
\hline \multirow{2}{*}{ Characteristics } & \multicolumn{3}{|c|}{$\mathrm{n}(56)$} & \multirow{2}{*}{$\%$} & \multirow{2}{*}{$\mathrm{p}^{\mathrm{a}}$} \\
\hline & SU & ISU & $\mathrm{CU}$ & & \\
\hline \multicolumn{6}{|l|}{$\overline{\operatorname{Sex}}$} \\
\hline Male & 28 & 15 & 18 & 36.3 & \multirow{2}{*}{0.028} \\
\hline Female & 28 & 41 & 38 & 63.7 & \\
\hline \multicolumn{6}{|l|}{ Age } \\
\hline$\leq 18$ years & 3 & 7 & 4 & 8.3 & \multirow{2}{*}{0.363} \\
\hline$>18$ years & 53 & 49 & 52 & 91.7 & \\
\hline \multicolumn{6}{|l|}{ Living type } \\
\hline Boarding house & 32 & 35 & 29 & 57.1 & \multirow{4}{*}{0.068} \\
\hline Dormitory & 4 & 7 & 0 & 6.5 & \\
\hline With parents & 16 & 12 & 23 & 30.4 & \\
\hline Wali $^{*}$ & 4 & 2 & 4 & 6.0 & \\
\hline \multicolumn{6}{|l|}{ Educational background } \\
\hline Pesantren ${ }^{* *}$ & 47 & 16 & 54 & 83.9 & \multirow{2}{*}{$<0.001$} \\
\hline Non-pesantren & 9 & 40 & 2 & 16.1 & \\
\hline \multicolumn{6}{|l|}{ Year of study } \\
\hline Year I - II & 5 & 19 & 18 & 25.0 & \multirow{3}{*}{$<0.001$} \\
\hline Year III - IV & 38 & 29 & 17 & 50.0 & \\
\hline Year $>$ IV & 13 & 8 & 21 & 25.0 & \\
\hline
\end{tabular}

${ }^{a}$ Chi-squared test, significant if $\mathrm{p}<0.05$; " people other than parents who live with the subjects and be responsible for them,

**Islamic boarding school; SU: State University; ISU: Islamic State University; CU: Catholic University 
Helmyati et al.

Table 2. Average score of knowledge, attitude, subjective norm, perceived behavioral control, and behavior related to halal food consumption

\begin{tabular}{|c|c|c|c|c|}
\hline \multirow{2}{*}{ Variables } & \multicolumn{3}{|c|}{$\mathrm{n}(56)$} & \multirow{2}{*}{$\mathrm{p}^{*}$} \\
\hline & SU & ISU & $\mathrm{CU}$ & \\
\hline Knowledge & $7.29 \pm 1.33$ & $7.43 \pm 1.23$ & $7.09 \pm 1.31$ & 0.380 \\
\hline Attitude & $51.52 \pm 3.71^{\mathrm{a}}$ & $49.80 \pm 3.52^{\mathrm{a}}$ & $47.61 \pm 5.19^{\mathrm{b}}$ & $<0.001$ \\
\hline Subjective norm & $3.59 \pm 2.51^{\mathrm{a}}$ & $2.68 \pm 2.44^{\mathrm{a}}$ & $1.48 \pm 1.67^{b}$ & $<0.001$ \\
\hline Perceived behavioral control & $27.57 \pm 3.41^{\mathrm{a}}$ & $27.59 \pm 3.54^{\mathrm{a}}$ & $25.46 \pm 4.16^{\mathrm{b}}$ & 0.003 \\
\hline Halal food consumption behavior & $9.18 \pm 1.66^{\mathrm{a}}$ & $9.18 \pm 1.84^{\mathrm{a}}$ & $7.98 \pm 1.87^{\mathrm{b}}$ & 0.004 \\
\hline
\end{tabular}

perscript letter in a row indicated there was no significant mean difference ( $p>0.05)$; SU: State University; ISU: Islamic State University; CU: Catholic University

the works of five sensory perceptions including sight, hearing, smelling, feeling, and touching. Knowledge is influential factor to form the person behavior. A behavior can change after sequential process including aspects of awareness of stimulus and interest to stimulus. The changes in behavior that is based on the knowledge, awareness, and positive attitude will last longer (Notoatmodjo 2007).

The level of knowledge about halal food in all subjects was relatively the same, even though they were from different universities. As one of the Islamic universities in Yogyakarta City, it does not signify that the students had better or solid understanding about halal food compared to CU students, in which Catholic University is a university with non-Islamic background. The open sources of knowledge such as electronic mass media is one of the reasons why people can gain a lot of knowledge about halal food even though they do not study about it through formal education. Ajzen and Joyce (2011) explained that the knowledge could have an effect or not towards behavior depending on how questions are given. A study by Musdyaningwati (2016) showed positive correlation between knowledge and the intention to buy halal products among students in Muhammadiyah University. Atmadi \& Widati (2013) stated that Lembaga Pengkajian Pangan, Obat-obatan, dan Kosmetika Majelis Ulama Indonesia (LPPOM-MUI) have shared the information about halal products through various mass media such as magazine, website, and exhibition but still lacking in social media.

Attitude can be defined as mental state of the individual that represents his positive, negative, or neutral feeling toward an object, concept, or idea which at last will precede the particular behavior. Attitude is an aspect consisted of three components, namely cognitive, affective and conative. Cognitive component is beliefs, ideas, and concepts of an object. Affective component is emotional aspect or feelings to an object, while conative component is a tendency to act in accordance with the attitude (Azwar 2009). This study found that attitude of the respondents toward halal food was significantly influenced their behavior of halal food consumption. Most respondents consumed halal food as they concern of religious obedience; it was reassuring, safe, healthy, and could affect their good behavior. Nevertheless, many respondents shown less positive feeling toward certified halal logo adhered in the packaging of the food. Most of them paid little attention to the logos, and ignore them.

Several studies have shown an interesting result in regards to the community the respondents belong to. A study by Ismoyowati (2015) in Central Java, where Moslems is the majority, showed that the halalness of the food is often come second after the taste. However, a study in a city in Kupang where Moslem is the minority showed high concern regarding the halal status and the label in packaged foods where $77 \%$ of the respondents always checked for halal logo and $97 \%$ of the respondents avoid to eat halal food side by side with non-halal food (Yuwono 2017). It could be due to the attitude of being the minority in a non-Moslem community in which increased the social solidarity and awareness towards halal food.

In theory of planned behavior, subjective norm is described as a perception on what other people assume that one should or should not do a particular behavior (Ajzen 1991). There might be demand from family, friends, or anyone who to a certain extent influenced people to follow certain behavior norms around them. In the case of halal food consumption, people surrounding the individuals have a role to influence them to consume 
halal food. Otherwise, negative image will be addressed if they do not comply to the norm.

There were two subjective norms used in this study. The first was motivation to consume halal food which came from friends in university, lecturer, student organization, and curriculum support through the lecture. The second was negative judgment which would come from friends in university, lecturer, and student organization to subjects if they did not consume halal food. Subjective norm may not influence human behavior if the norm is merely based on interpersonal influence such as friends, families, or colleagues and is not based on external influence such as mass media, public opinion, and many others ( $\mathrm{Al}$ Swidi et al. 2014, Awan et al. 2015).

Perceived behavioral control is described as perception of the extent to which the behavior is assumed to be controllable. It assesses the degree to which people perceive that they have control over enacting to perform a behavior (Anggraini 2016). The concept of perceived behavioral control consists of two components, 1) the availability of resources which supports a behavior to be performed such as time, money, chance, or skill; 2) belief on own ability to perform those behavior. The stronger perceived behavioral control, the easier is behavior will be performed (Ajzen 1991).

\section{Prediction of the halal food consumption be- havior from attitude, knowledge, subjective norm, and perceived behavioral control.}

The multiple regression analysis was conducted in each university to understand how much the independent variables could predict the dependent variable in each setting (SU, ISU, and CU). As shown in Table 3 which shows predictive value of halal food consumption behavior in each university, the statistics prediction were significant just in $\mathrm{SU}\left[\mathrm{F}(4,51)=3.908, \mathrm{R}^{2}=0.235\right]$ and $\mathrm{CU}\left[\mathrm{F}(4,51)=3.705, \mathrm{R}^{2}=0.225\right]$ with $\mathrm{p}<0.05$. However, the value of $\mathrm{R}^{2}$ in ISU was only $16.5 \%$ which was not significant ( $p>0.05)$. Meanwhile, there was only the attitude which significantly predict the value of halal food consumption behavior in SU and CU and two variables of knowledge and attitude were significantly predict the value of the dependent variable in ISU $(p<0.05)$.

Attitude is very important to show how an individual evaluates a behavior as negative or positive. According to the study by Hall \& Sevim (2006), attitude is the second factor after the subjective norm to affect the intention of consum- ing halal food among Turkish immigrant. Other studies also proved that attitude significantly influence the intention of doing something (Nursalwani \& Zulariff 2017; Khalek 2012). The behavior of SU and CU subjects was prone to be affected by attitude. It means that when consuming halal foods, subject relied more on their assessment of the behavior. Alhazmi (2013) mentioned that some factors affecting attitude towards halal food consumption are religious commitment, social pressure, the need to please Allah, personal choice, and getting family approval. In this research, the attitude score is higher in SU than in ISU and CU. Although the score in CU is the lowest, it also adds significant value to the prediction equation towards halal food consumption. These findings proved that university background did not act as a barrier for the Moslem students to do their religious obligations.

The score of knowledge is significantly higher in ISU than in SU and CU. It is supported by the fact that ISU has Islamic education background which lead to a better knowledge among the students about the halal food. A study by Sadeeqa et al. (2013) stated that knowledge has a positive relationship with the perception. However in this study, although the knowledge plays significant role in predicting halal food consumption behavior among ISU students, the regression factor of the equation is lower than SU and CU. These findings extend the possibility to predict the halal food consumption behavior from Ajzen's theory of planned behavior. By observing the predicting factors of halal food behavior, it is possible to control those factors in order to improve the behavior in the future. In this study, the effect of the perceived behavioral control reflected by the subjects' belief on their ability to perform a behavior. It was supported by the fact that the subjects come from 3 different university backgrounds. Although the background is different, the Moslem students from Catholic University still have a good score of knowledge, attitude, subjective norm, and perceived behavioral control compared to the State and Islamic University. The score of each aspect in CU could be the lowest, but it could also play a role as the predicting variables on halal food consumption behavior. It implies that even though they were in non-Moslem environment, they still have a positive attitude toward consuming halal food.

This study found that perceived behavioral control did not affect the intention to consume 
Helmyati et al.

Table 3. Prediction of halal food consumption behavior in each university

\begin{tabular}{|c|c|c|c|c|c|}
\hline Variables & Coefficients $(\beta)$ & SE & $95 \% \mathrm{CI}$ & $\mathrm{p}$ & $\mathrm{R}^{2}$ \\
\hline \multicolumn{6}{|l|}{ State University (SU) } \\
\hline Intercept & -2.394 & 3.512 & -9.445 to 4.657 & 0.499 & \multirow{5}{*}{$0.235^{*}$} \\
\hline Knowledge & 0.149 & 0.173 & -0.198 to 0.496 & 0.392 & \\
\hline Attitude & 0.205 & 0.061 & 0.082 to 0.328 & 0.002 & \\
\hline Subjective norm & 0.009 & 0.102 & -0.197 to 0.214 & 0.932 & \\
\hline Perceived behavioral control & 0.003 & 0.065 & -0.134 to 0.127 & 0.958 & \\
\hline \multicolumn{6}{|l|}{ Islamic State University (ISU) } \\
\hline Intercept & -1.816 & 3.968 & -9.782 to 6.151 & 0.649 & \multirow{5}{*}{$0.165^{* *}$} \\
\hline Knowledge & 0.446 & 0.192 & 0.059 to 0.832 & 0.025 & \\
\hline Attitude & 0.174 & 0.079 & 0.015 to 0.333 & 0.032 & \\
\hline Subjective borm & -0.132 & 0.105 & -0.342 to 0.079 & 0.215 & \\
\hline Perceived behavioral control & -0.023 & 0.073 & -0.171 to 0.124 & 0.751 & \\
\hline \multicolumn{6}{|l|}{ Catholic University (CU) } \\
\hline Intercept & 0.298 & 2.280 & -4.278 to 4.875 & 0.896 & \multirow{5}{*}{$0.225^{* * *}$} \\
\hline Knowledge & -0.135 & 0.184 & -0.505 to 0.235 & 0.466 & \\
\hline Attitude & 0.162 & 0.053 & 0.056 to 0.267 & 0.003 & \\
\hline Subjective norm & -0.049 & 0.147 & -0.344 to 0.246 & 0.740 & \\
\hline Perceived behavioral control & 0.040 & 0.067 & -0.094 to 0.175 & 0.551 & \\
\hline
\end{tabular}

halal food $(\mathrm{p}>0.05)$. It was in contrast with the study by Nursalwani \& Zulariff (2017) who stated that perceived behavioral control significantly affected the behavior toward halal labeled chocolate bar consumption in Malaysia. Meanwhile in China, attitude and perceived control could predict the intention to buy halal meat among Moslem (Ali et al. 2017). However, another study by Hall \& Sevim (2016) mentioned that perceived behavioral control has lower effect than the subjective norm and attitude toward halal food consumption among Turkish immigrant. It suggested that perceived behavioral control may affected by various factors such as the sample size, socio-demographic factors, and others. Perceived behavioral control could affect the human behavior as people are more likely to engage in behaviors in which they have control over and are prevented from carrying out behaviors over which they feel to have no control (Rahim \& Junos 2012). Study by Golnaz et al. (2010) stated that food safety was perceived as a behavior control $(\mathrm{p}=0.05)$ which significantly affected the intention to consume halal food.

In this study, the influence of perceived behavioral control was stronger than subjective norm, but much weaker than the effect of attitudes toward halal food consumption behavior. It could be one of the reasons why the size of regression coefficient is low. Perceived behavioral control could directly increase the effort to achieve a goal (Nursalwani \& Zulariff 2017). It means the lower perceived behavioral control, the lower intention of conducting certain behavior.

The results of this study were interesting since although the score of attitude, subjective norm, and perceived behavioral control in each university was significantly different, attitude is the only one which add significant value in the prediction equation in SU and CU. Meanwhile, although the score of knowledge was not different in three universities, it adds significant value in the prediction equation of ISU as well as the attitude aspect. This finding is consistent with the theory of planned behavior that stronger the attitude towards behavior the easier it is to perform that behavior (Ajzen 1991). It also implies that generaly Non-Moslems environment is not a deterrence to cultivate a positive attitude and increase self-control for consuming halal food.

The present study has several limitations in the aspects of the theory of planned behaviour use. According to Ajzen (1991), there were several dimensions following each aspect of planned behaviour theory. Attitude consists of behavioural belief and outcome evaluation, sub- 
jective norms consist of normative belief and motivation to comply while perceived behavioural control consists of control belief and power of control factor. However, the present study only covered the general aspect and did not evaluate the dimension of each aspect. It makes further research necessary in order to extend the explanation regarding which factors are influencing the behavior towards halal food. This study is also not examining the role of external resources such as money, time, chance, or skill which is also affect the halal food consumption behavior.

The findings from this research have an implication for further research and practice. To assess the impact of the perception of behavioral control on behavior of halal food consumption, it is advisable to develop the concept of perceived behavioral control by adding the availability of resources such as money, time, or the availability of halal products in the market as factors which may affect the formation of behavior.

\section{CONCLUSION}

The score of attitude and subjective norm is highest in State University while perceived behavioral control and halal food consumption behavior is highest in State University and Islamic State University. According to multiple regression test, the score of attitude was significantly affecting the prediction of halal food consumption behavior in State University, Islamic State University, and Catholic University. The halal food consumption behavior among Moslem students in the three universities in general could be predicted from the aspect of the theory of planned behavior. Further research is needed to examine whether there is another factor affecting halal food consumption behavior and how to improve it.

\section{ACKNOWLEDGEMENT}

We thanked Majelis Ulama Indonesia Yogyakarta for providing the literatures and Prof. Jacob Che Man (alm) from Universiti Putra Malaysia who encouraged the researcher to study about halal food consumption behavior. The authors have no conflict of interest.

\section{REFERENCES}

Aditami S. 2016. The analysis of halal product purchase intention using theory of planned behavior (TPB): An application on bakery product consumption. [Undergraduate
Thesis]. Surakarta: Muhammadiyah University.

Ajzen I. 1991. The theory of planned behavior. Organ Behav Hum Decis Process 50(2):179-211.

Ajzen I, Fishbein M. 2005. The Influence of Attitudes on Behavior. The Handbook of Attitudes Chapter 5 pp 173-221.

Ajzen I, Joyce NM. 2011. Knowledge and the prediction of behavior: The role of information accuracy in the theory of planned behavior. Basic Appl Soc Psych 33(2): 101-117.

Al Swidi A, Huque SMR, Hafeez MH, Shariff MNM. 2014. The role of subjective norms in theory of planned behavior in the context of organic food consumption. Br Food J 116(10):1561-1580.

Alam SS, Sayuti NM. 2011. Applying the theory of planned behavior (TPB) in halal food purchasing. Int J Commerce Manag 21(1):8-20.

Alhazmi HKH. 2013. New Zealand Muslim consumer attitudes towards purchasing halal food. [Thesis]. New Zealand: Auckland University of Technology.

Ali A, Xiaoling G, Sherwani M, Ali A. 2017. Factors affecting Halal meat purchase intention: Evidence from international Muslim students in China. Br Food J 199(3):527541.

Anggraini FRR. 2016. The role of perceived behavioral control and subjective norms to internal auditor's intention in conveying unethical behavior: A case study in Indonesia. Review of Integrative Busisness and Economics Research 5(2):141-150.

Anjani G, Afifah DN, Pramono A, Hunaefi D, Wijayanti HB. 2008. The halalness of Indonesian street food: Problem and solution? $2^{\text {nd }}$ IMT-GT International Halal Science Symposium on "Scientific Approach towards Halalness Authentication". Available: https://www.researchgate.net/publication/2751 (Accessed June $6^{\text {th }} 2018$ ).

Atmadi G, Widati SRW. 2013. Strategi pemilihan media komunikasi LPPOM MUI dalam sosialisasi dan promosi produk halal di Indonesia. Jurnal Al-Azhar Indonesia Seri PranataSosial 2(2):87-97.

Awan H, Siddique A, Haider Z. 2015 Factors affecting Halal purchase intention - evidence from Pakistan'd Halal food sector. Management Research Review 38(6):640-660.

Aziz M. 2017. Perspektif Maqashid Al-Syariah dalam penyelenggaraan jaminan produk 
halal di Indonesia pasca berlakunya Undang-Undang Nomor 33 tahun 2014 tentang jaminan produk halal. Al Himah Jurnal Studi Keislaman 7(2).

Azwar S. 2009. Penyusunan Skala Psikologi. Yogyakarta: Pustaka Pelajar.

Fahmi S. 2017. Halal labeling effect on muslim consumers attitude and behavior. International Conference of Organizational Innovation (ICOI 2017). Advances in Intelligent Systems Research 131:56-62.

Fithriana A, Kusuma RP. 2018. Implementasi kebijakan pangan halal Indonesia: Keunggulan kompetitif dalam tren pangan halal di Asia Tenggara. Global Insight Journal 3(1):1-18.

Golnaz R, Zainalabidin M, Mad Nasir S, Eddie Chiew FC. 2010. Non-Muslims' awareness of halal principles and related food product in Malaysia. Int Food Res J 17:667-674.

Hall EE. Sevim N. 2016. Halal food consumption intention by Turkish immigrants. IJBMI 5(11):36-40.

Indonesia Ministry of Religion. 2013. Perilaku komunitas Muslim perkotaan dalam mengonsumsi produk halal. Jakarta: Indonesian Ministry of Religion.

Ismoyowati D. 2015. Halal food marketing: A case study on consumer behavior of chicken-based processed food consumption in central part of Java, Indonesia. Agriculture and Agricultural Science Procedia 3(2015):169-172.

Khalek AA, Ismail SHS. 2015. Why are we eating halal - Using the theory of planned behavior in predicting halal food consumption among generation $\mathrm{Y}$ in Malaysia. Int $\mathrm{J}$ Soc Sci Human 5(7):608-612.

Khattak JZK, Mir A, Anwar Z, Wahedi HM. 2011. Concept of halal food and biotechnology. Adv J Food Sci Technol 3(5):385389.

Listyoningrum A. 2012. Analysis of Muslims consumers buying intention on product which its halal certificate were not renewed. Jurnal Ekonomi dan Keuangan Islam 2(1):40-51.

Magfiroh. 2015. Factors affecting the intention to buy packaged food with LPPOM-MUI halal label. Jurnal Economia 11(2):169-176.

Musdyaningwati T. 2016. Tingkat korelasi pengetahuan dengan sikap keputusan membeli makanan halal pada Mahasiswa Universitas Muhammadiyah Semarang. [Undergraduate Thesis]. Semarang: Muhammadiyah University.
Notoatmodjo S. 2007. Promosi Kesehatan dan Ilmu Perilaku. Jakarta: Rineka Cipta.

Nugroho YA. 2011. It's Easy, Olah Data dengan SPSS. Yogyakarta: PT. Skripta Media Creative.

Nursalwani M, Zularif AL. 2017. The effect of attitude, subjective norm and perceived behaviour control towards intention of Muslim youth at public universities in Kelantan to consume halal labelled chocolate bar product. Canadian Social Science 13(2):43-48.

Othman B, Shaarani SM, Bahron A. 2016. The potential of ASEAN in halal certification implementation: A review. J Soc Sci \& Hum 24(1):1-24.

Rahim NA, Junos S. 2012. The halal product acceptance model for the religious society. Business \& Management Review 3(1):1725.

Sadeqaa S, Sarriff A, Masood I, Saleem F, Atif M. 2013. Knowledge, attitude and perception regrading halal pharmaceuticals among general public in Malaysia. IJPHS 2(4):143-150.

Soesilowati ES. 2009. Peluang Bisnis Produk Halal di Pasar Global-Perilaku Makanan Halal Konsumen Muslim. Jakarta: LIPI Press.

Soesilowati ES. 2011. Perilaku muslim dalam konsumsi makanan halal. Case: Moslem in Banten. Accessed from http;//ekonomisyariah.org. (Accesed on $1^{\text {st }}$ July 2011).

Soesilowati ES, Yuliana CI. 2013. A comparison of consumers's behaviour in Muslim mayority and minority areas. Jurnal Ekonomi dan Pembangunan 21(2):167-178.

Soon JM, Wallace CA. 2017. Application of theory of planned behaviour in purchasing intention and consumption of halal food. Nutrition \& Food Science 47(5):635-647.

Sugiyono. 2009. R\&D, Kualitatif, dan Penelitian Kuantitatif. Bandung: Alfabeta.

The Pew Forum on Religion and Public Life. 2011. The Future of The Global Muslim Population [Internet]. Washington: The Pew Forum on Religion and Public Life. Tersedia dalam : $<$ http://pewforum.org $>$ [Accessed on $3^{\text {rd }}$ March 2011].

Yuwono DB. 2017. Kepedulian umat Islam perkotaan terhadap kehalalan produk makanan pengusaha kecil-mikro (Kasus di komunitas minoritas Muslim di Kota Kupang, Nusa Tenggara Timur). Panangkaran 1(1):111-137.

J. Gizi Pangan, Volume 14, Number 1, March 2019 